\title{
IAMJ
}

INTERNATIONAL AYURVEDIC MEDICAL JOURNAL

\section{APPLIED ASPECT OF SHADCHAKRAS AND ITS IMPORTANCE IN SHARIR VIGYAN}

\section{Jyoti Dhakad $^{1}$, Pankaj Gupta ${ }^{2}$}

${ }^{1} \mathrm{PG}$ scholar (2 ${ }^{\text {nd }}$ Year), Rachna Sharir Dept., ${ }^{2}$ M.D. and Ph.D. (Associate Professor);

Pt. Khusilal Sharma govt. (Auto.) ayurvedic College and hospital Bhopal Madhya Pradesh, India

Corresponding Author: jyotidhakad22@gmail.com

\section{https://doi.org/ $10.46607 / 25 i a m j 08092020$}

(Published online: September 2020)

Open Access

(C) International Ayurvedic Medical Journal, India 2020

Article Received: 09/08/2020 - Peer Reviewed: 01/09/2020 - Accepted for Publication: 01/09/2020

Check for updates

\begin{abstract}
The Chakra is thought to be an energy point or node in the subtle of body. which is thought to flow among them along pathway called Nadis. There are six primary Chakras namely Muladhara, Swadhithana, Manipura, Anahat, Visudha, Ajna Chakra. Sthana of Muladhara Chakra and Swadhithana Chakra is Ling and Gud which can be correlate with inferior hypogastric and sacral plexus. Sthana of Manipura Chakra is Nabhi and is represented by solar plexus. Hrudiya is the sthana of Anahat Chakra and it is represented by cardiac plexus. Sthana of Visuddha Chakra is kantha and is represented by cervical plexus. Sthana of Ajna chakra is between eyebrow and it is Avyakta (union of Prakriti and Purush) hence not related to any plexus. these are directly related to physiological as well as physic centers whose structures correspond more or less with traditional description.
\end{abstract}

Keywords: Shadchakra, Sthana, Nadi,

\section{INTRODUCTION}

The literal meaning of Chakra is 'wheel' or 'circle' but in Yogic context a better translation of the Sanskrit word is 'vertex' or 'whirlpool'. The Chakras are vertices of psychic energy and they are visualized and experienced as circular movement of energy at particular rates of vibration. Chakras are an energy point, which is thought to flow among them along pathway called Nadis. Chakras are believed to be a part of the subtle of body, not to the physical body, more importance is given to Shadchakra in Yoga Vigyan for stability. Chakras are six in number these primary six Chakras namely Muladhara, Swadhisthana, Manipura, Anahat, 
Visuddha, and Ajna Chakra. These six Chakras are situated along the spine and each has special function. These Chakras are placed at regular interval, one above the other. These six Chakras serve as swishes for turning on different parts of brain. The awakening which is brought about in the Chakras is conducted to higher centers in the brain via Nadis. One more Chakra are described in Ayurvedic literature Sahasrara "is supreme; It is final culmination of Kundalini Shakti. It is the seat of higher awareness. Sahasrara is situated at the top of head and is physically correlated to the pituitary gland, which chakra each and every gland and system of the body. (Satyanand, 2013)

Nadis are not nerves but rather channels for the flow of consciousness. The meaning of $\mathrm{Nadi}$ is flow just as the negative and positive forces of electricity flow through complex circuit. According to Tantras there are 72000 or more. This network of Nadis there are 10 main channels and of these 10, three are most important for they control the flow of Prana and consciousness with in all the other Nadis of the body.

These 3 Nadis are Ida, Pingla and Sushmna, are flows inside the central canal of the spinal cord, Ida and Pingla simultaneously flow on the outer surface of the spinal cord, Still within the body vertebral column. These 3 Nadis begin in Muladhara in the pelvic floor. From there Sushumna flows directly upwards within the central canal, while Ida passes to the left and Pingla to the right. At Swadhisthana Chakra or sacral plexus, the 3 Nadis come together again and Ida and Pingla cross over one another. Ida passes up to the right, Pingla to the left and Sushumna continues to the flow directly upward in the central canal. The 3 Nadis come together again at Manipura Chakra, the solar plexus and so on. Finally, Ida, Pingla and Sushumna meet in Ajna chakra. ${ }^{1}$

Kundalini as it represents the coming conscious-ness of mankind. Kundalini is situated at the root of the spinal column. In the masculine body it is in perineum, between the urinary and excretory organs. In the female body its location is Kundalini is a dormant energy. As kundalini ascends is passes through each of the Chakras which are interconnected with the different silent areas of the brain. Men discovered Prana and called it Prana Shakti, in Tantra they called it Kundalini. ${ }^{2}$

The various esoteric cults and spiritual systems use different symbols to represent the chakras in a Tantra and Yoga the Chakras are symbolized by lotus flowers. It symbolized man's growth from the lowest states of awareness to the higher states of consciousness.

The Chakras relate to anatomical, physiological and psychic centers whose structures correspond more or less with the traditional description's. These nerve centers are not situated inside the spinal cord itself but lie like junctions on the interior wall of the spinal column. If you cut the spinal cord transversely at different levels, you can see that the gray matter in the cross section resembles the lotus shape and the ascending and descending tracts of nerve fibers control the different physiological function of that portion of the body. There are six Chakras in the human body which are directly connected with the higher unillumined centers of the brain. ${ }^{3}$

\section{Traditional Description of Chakra-}

Muladhara Chakra-Sanskrit word 'Mool' means 'root' or 'foundation' and that is precisely what this Chakra is, Appearance like a lotus of 4 patels, situated a 2 fingers above the Gudha and one finger below the Medra, 4 fingers in width, chief Vayu-Apana, colour- deep red lotus, Mahabhuta-at the centre of this lotus is present squre region of Prithvi, Prithvi beejo-cryptic latter 'lam', Beeja barer-Airvata (king of elephants\}. Muladhara does not have Kshetram.

Swadhisthana Chakra-The Sanskrit word 'Swa' means one's own and Adthisthana means dwelling place one residence. Second Chakra is situated at the level of coccyx or tail bone. This is small bony bulb which can be felt just above the anus, it is an-atomically very close to Muladhara Chakra in both male and female bodies Swadhithana Kshetram "is in the front of the body at the level of the pubic bone, it has 6 petals it stalk is called Swadhithana, the colour of the lotus is vermilion. It's presiding adept is called Bala, the element of Chakra is water symbolized by crescent moon within the pericarp of the lotus and Beeja Mantra of the chakra is 'Varn'. The chief Vayu of Swadhithana, is Apana. 
Manipura Chakra-Sanskrit word Mani meaning 'jewel' and Pura meaning is city' therefore Manipura literally means city of jewel in the Tibetan traditions, this Chakra is known as Manipadma which means jeweled lotus. Manipur chakra is located directly behind the naval on the inner wall of the spinal column. The Kshetram is situated right at the naval. This chakra is anatomically related to the solar plexus which control the digestive fire and heat regulation in the body. It is of golden colour having 10 patels. At the naval region, there is an important junction where two of these vital forces Prana and Apana meet. The chief Vayu of Swdhisthan" is Saman. Mantra of Manipura 'Ram Element of Chakra is Agni.

Anahat Chakra-The word Anahat actually means 'unstuck' or 'unbeaten' this center is known as such because of its relationship with the heart, which throbs, beat or vibrates to a constant unbroken rhythm. Anahat Chakra is situated in the spinal column on the inner wall, directly behind the canter of the chest. The Kshetram is the heart and although Anahat is known as the heart center. It has 12 petals, its colour is deep blood red it has seed of Vayu, 'Yarn' and is very pleasant spot. The inner region is hexagonal in shape, representing the air element. The inverted triangle is the symbol of creativity.

Visuddhi Chakra- Visuddhi Chakra is known as 'the purification center the Sanskrit word Suddhi means 'to purify Visuddhi is also known as the nectar and poison center. Visuddhi chakra is in the cervical plexus directly behind the throat pit. The Kshetram is in the front of the neck at the front pit or thyroid gland. The physiological concomitants of Visuddhi are pharyngeal and laryngeal nerve plexi. It is represented by a dark grey colored lotus; it has 10 petals correspond to the number of Nadis associated with this center. Representing element of ether or Akash. The Beejo Mantra is 'Ham' and the chief Vayu is Udana.

Ajna Chakra-Our reflection on the psychic centers, began from Ajna Chakra. According to tradition, $M u$ ladhara Chakra is generally designated as the first Chakra. Ajna Chakra is point of confluence where the three main Nadis or forces Ida, Pingla and sushumna, merge Sahstra e into one stream of consciousness and flow up to the crown center.

Ajna chakra is located in the brain, directly behind the eyebrow center. It is at the very top of spinal cord, at the medulla ablongata. It has the letter 'Ham' and 'Ksh'. It should be mentioned here that the pineal gland is the physical concomitant of Ajna Chakra and pituitary gland of Sahasrara. ${ }^{4}$

\section{Relation Between Chakra and Rachna Sharir -}

Muladhara Chakra- It is represented by inferior hypogastric plexus both are in triangular in structure, inferior hypogastric plexus work as axle of this Muladhara Chakra. It is definite neuro endo-vascular entity in the vicinity of pelvis, which gov-erns, regulate and mediates all pelvic function through small plexus to all pelvic organs. The 4 Dalas i.e. Vama, Sama, Shama, Shhama represent the 4 sub plexuses of inferior hypogastric plexus which are uterine, vaginal, middle rectal and vesical plexus. ${ }^{5}$

Swadhithana Chakra-It is represented by sacral plexus and Apan Vayu has an influence on the organ in the pelvic region there are different entities which play important role in reproduction. Swadhisthana Chakra may be correlated with sacral plexus on the basis of its location, its numeration and its traumatic effect. The 6 Dala may be correlated to the branches of sacral plexus. The function of Swadhisthana Chakra" is said to be procreation i.e. reproduction. Similarly, hypogastric plexus has a major role in reproduction trauma to the hypogastric plexus in male and female. So, it is important to keep Swadhisthana Chakra activated by practicing the Asanas and Pranayama to maintain. ${ }^{6}$

Manipura Chakra- It is representing by colic or solar plexus. The role of solar plexus is to absorb and assimilate Prana from the sun. Being related to the sense of sight it is associated with the eye movement in endocrinal system Manipura is said to be associated with the pancreases and outer ad-renal gland (the adrenal cortex). This gland create important hormones involved in digestion, converting food into energy for the body, in the same way Manipura radiate Prana throughout the body Manipur Chakra has 10 dals and coeliac plexus has around 10 subdivision which are phrenic, hepatic, lineal, superior gastric, supra renal, renal, seprmatic, 
superior mesenteric, abdominal aortic, inferior mesenteric. $^{7}$

Anahat Chakra It is represented by cardiac plexus. The location of Anahat Chakra is said to be heart. As per Yog text it has been stated as the Anahat Chakra has the role in governing the heart rate. Anahat Chakra modulate the heart rate and cardiac output. Anahat Chakra is the center of entire system it connects the 3 lower physical and emotional centers to the higher mental and spiritual centers. Chakra is assigned to the element air to sense of touch This indicate the flexibility of the heart $^{8}$

Visuddhi Chakra: It is represented by cervical plexus or brachial plexus. It is originating from the ventral branches of the last 4 cervical and 1 st thoracic spinal nerve supplying structures in the neck region. The chakra is situated precisely where that little indentation is in the throat, the organ of voice, the air passage between the lower pharynx and the trachea formed by cartilage thyroid, coracoid, epiglottis, paired arytenoids corniculate and cuneiform. ${ }^{9}$

Ajna Chakra: It is be levied by some to be a dormant organ that can be awakened to enable telepathic communication. Ajna Chakra "is located between the eyebrows also called third eye chakra. In physical body there are two eyes which views objects upside down and send image and makes it appear right side up to us but in human body was another physical aye i.e. third aye or spiritual eye which is correlated with the pineal gland. Ajna Chakra is best balance through meditation and Pra-nayama or Bramhari technique. ${ }^{10}$

\section{DISCUSSION}

Individual plexus is said to be related with chakra by considering the Sthana or important function of that plexus, organs as told in literature and relating is to the Sthana of Chakra and hence making a full circle of interrelationship between Chakra and plexus.

Muladhara Chakra govern the immune system, skeletal system (i.e. support) lower digestive or digestive tract e.g. colon, rectum, anus. If the energy is blocked or unhealthy it might manifest in inferior hypogastric plexus this plexus is a paired structure with each situated on the side of the rectum and vagina in the female for this reason, injury to this structure is known complication of surgery and may cause urinary dysfunction and specifically urinary incontinence. Urodynamic will reveal a poorly complaint bladder, with bladder neck in-competence and fixed external sphincter line. ${ }^{11}$

Swadhisthana Chakra controls lymph, mucus, urine, seat of kidney energy, control maintenance of water level in the body And this chakra correlate with sacral plexus, a sacral plexus, usually caused by trauma, nerve compression, vascular disease or infection symptoms may be include pain loss of motor control and sensory deficits.

Manipura Chakra is a seat of digestive system and as per location of manipura Chakra celiac or solar plexus can be correlated if energy is block it might manifest in solar plexus. This can cause the diaphragm to spasm, resulting in difficulty in breathing sensation commonly known as the wind knocked out of you. A blow of this region can also affect the celiac plexus itself, possibly interfering with the function of the viscera, as well as causing great pain.

Anaht Chakra including heart and lungs. Anahat Chakra is control respiration system and circulatory system. This is directly correlated with cardiac plexus. A malfunctioning of Anahat Chakra may express in various ways. It can manifest itself as upper back and shoulder problem Asthma, heart conditions, shallow or rapid breathing and lung diseases.

Visuddhi Chakra has control over the region of neck, throat, vocal cords, trachea, mouth, teeth and gums, vocal cords. This Chakra can be correlated with cervical plexus injury to various nerves of the cervical plexus present with various clinical symptoms related to the specific function of nerves. Cervical plexopathy directly occurs as a result direct invasion from contiguous neck, soft tissue tumors or indirectly from regional lymph node metastasis from head and neck, squamous cell carcinomas, lymphoma or lung and breast adenocarcinoma.

Ajna chakra is located between the eyebrow and also called third eye, Chakra can be correlated with pineal gland it is associated with depression, peptic ulcer, and sexual dysfunction. 


\section{CONCLUSION}

By considering the important Karma of that particular Chakra and Karma of nerve plexus as told in modern literature and relating it to the Sthana of Chakra we may conclude full circle of interrelationship resulting in establishing the probable relation between Chakra and Nerve plexus. Each chakra may be controlling the function of related nerve plexus through sthana. If energy is block or unhealthy it might manifest the function of related plexus and they may cause diseases. So, if we save, protect and treat the location of chakra we can awaken the cycle.

1. Muladhara Chakra is represented by inferior hypogastric plexus and govern the function of this area.

2. Swadhisthana chakra is represented by sacral plexus and maintain the function of sacral region.

3. Manipura chakra is related with celiac or solar plexus and regulate the function of digestive system.

4. Anahat chakra is correlated with cardiac plexus regulated the function of respiratory and cardiac system.

5. Visuddha chakra has control over cervical plexus and regulate the functions of cervical diseases.

6. Ajna chakra is correlate with Pinal gland and regulate it.

\section{REFERENCES}

1. Sarswati Swami Satyanand, Kundlini Tantra: 2013. Bihar School Of Yoga; Yoga Publication Trust. Section 4. Chapter 3. Page No.203.

2. Sarswati Swami Satyanand, Kundlini Tantra: 2013. Bihar School Of Yoga; Yoga Publication Trust. Section 1. Chapter 2. Page No.11.

3. Sarswati Swami Satyanand, Kundlini Tantra: 2013. Bihar School Of Yoga; Yoga Publication Trust. Section 1. Chapter 2. Page No.76.

4. Sarswati Swami Satyanand, Kundlini Tantra: 2013. Bihar School Of Yoga; Yoga Publication Trust. Section 2. Chapter 1-10. Page No.72-111.

5. K. M. Sweta, H. M. Awaxthi, Et Al. Physio-Anatomical Resemblance Of Inferior Hypogastric Plexus With Muladhara Chakra: A Cadaveric Study. AYU2017, 3b Kamath Nagraj, Kulkarni Pratibha, Et Al.
6. Neha Balkrishna, International Journal Of Science And Research. Nanded 21st June. Physio-Anatomical Resemblance Of Inferno Hypogaxtrie Plexus With Chakra

7. Sachin Khedikar.Researchgate.Com.Nov.2016

8. Review Study Of Anahat Chakra W.S.R. To Cardiac Plexus.

9. B D Chaurasia S Human Anatoin»: Krishna Garg.5th Edition, New Delhi: CBS Publication,2010

10. Gray's Anatomy Tor Student: Richard L. Drake, A. Waynevogl, Adam W.M. Mitchell, 1" South Edition, 2015

11. Gray's Anatomy Tor Student: Richard L. Drake, A. Waynevogl, Adam W.M. Mitchell, 1" South Edition, 2015

\section{Source of Support: Nil Conflict of Interest: None Declared}

How to cite this URL: Jyoti Dhakad \& Pankaj Kumar Gupta: Applied Aspect Of Shadchakras And Its Importance In Sharir Vigyan. International Ayurvedic Medical Journal \{online\} 2020 \{cited September, 2020\} Available from: http://www.iamj.in/posts/images/upload/4456 4460.pdf 